\title{
ACCOUNTING PROBLEMS IN TERMINATIONS $\dagger$
}

\author{
Dundas Peacock*
}

The problems incident to World War II war contract terminations are vastly greater and more complex than at the end of World War I because the war production program now in force is more than ten times that of World War I and involves a much larger proportion of the manpower and productive facilities of the country. It is now generally recognized that postwar problem number one will be that of prompt settlement of terminated contracts and that the consummation of most other postwar plans will depend, to a very great extent, upon the satisfactory solution of this problem. It is imperative that settlement for terminated war contracts be accomplished in a speedy, equitable, and efficient manner; otherwise, companies now engaged in war production will be unable to convert rapidly to peace production and, therefore, will be unable to maintain the high level of employment that will be needed to avoid national economic chaos following the war.

Sight has been lost of late of the accounting problems incident to war contract terminations while Government procurement and administrative agencies and congressional committees have attempted to determine (a) who shall be held responsible for administration of war contract terminations, (b) how the Government's interests can be protected and to what extent they should be protected, and (c) what provisions should be made to assure that war contractors will receive prompt payment of at least a substantial portion of their claims to aid in the financing of a rapid and efficient reconversion to peace production. Pending the solution of these highly controversial problems, it is unlikely that very much progress will be made with the accounting problems.

As a result of inter-governmental department controversy, a Joint Contract Termination Board was formed of procurement agency representatives under the chairmanship of Mr. John M. Hancock, and direction of Mr. Bernard Baruch. This Board prepared a uniform termination article for fixed-price supply contracts, supplemented by a statement of principles for determination of costs upon termination of Government fixed-price supply contracts, ${ }^{1}$ which was issued under a directive

t The Contract Settlement Act of 1944 , passed after this article was written, does not conflict with nor invalidate the Uniform Termination Article nor the Principles of Cost Determination which were the bases of this article.

- C.P.A. (Pa.) r932. Controller of Elliott Company, Jeannette, Pennsylvania. Member of The American Institute of Accountants. Member of the Pennsylvania Institute of Certified Public Accountants. Member of the Controllers Institute of America and Chairman of its Committee on War Contract Termipation Policies and Procedures. Member of Accounting Committee of Machinery and Allied Products Institute. Contributor to accounting and business periodicals.

1 The text of the Uniform article and of the Statement of Principles of Cost Determination is set forth in the previously published Part $I$ of this symposium, at pages 509, 512 . 
order by War Mobilization Director Byrnes on January 8, 1944. All procurement agencies were thereafter directed to adopt that article and the statement of cost principles. On February 15, r944, Messrs. Baruch and Hancock submitted a report on war and post-war adjustment policies which explained the background of the uniform termination clause and made certain recommendations for legislation to be passed. Presumably, the uniform article and statement of cost principles set the stage for the administration of war contracts. However, several Senate and Congressional Committees have also been studying the termination problem and numerous bills have been submitted. As of this writing, it appears that Senate Bill S. I7x8 submitted on February II, I944, by Senator James E. Murray, Chairman of a subcommittee of the Senate Military Affairs Committee, is likely to be passed. That Bill agrees substantially with the report of Mr. Bernard Baruch, the greatest difference being that it provides for the creation of an Office of Contract Settlement to be headed by a Director of Contract Settlement to be appointed by the President, who would report periodically to Congress. This Bill provides that the General Accounting Office shall be authorized only to examine the records of the contracting agencies after final settlements for detection of fraud. This is a highly controversial provision and it is not possible to state at this time whether or not the authority of the General Accounting Office will be expanded. It is unlikely that the administrative procedures finally determined will differ much from the basic philosophies contained in the report of Mr. Baruch and in the uniform termination article and statement of cost principles issued by War Mobilization Director Byrnes on January 8 , I944.

When the uniform termination article for fixed-price supply contracts and the related statement of cost principles were issued on January 8, 1944 by the Director of War Mobilization, it was stated that these documents represented only the first step in developing a full set of clear-cut, workable policies on contract terminationbut only the first step. In the announcement published at the time of the release, it was stated, "To clarify some of the questions that are not covered in this termination article and cost statement, our objectives on some of the unsettled problems might be stated:

"I. How to apply the principles of this uniform termination article to subcontractors, is under careful consideration. A number of serious administrative problems are involved that require further study. Our objective is to have the same principles of contract settlement apply to subcontractors as well as prime contractors.

"2. As to payment, our objective is quick payment of what the Government owes so that our great productive capacity can be fully utilized for war and peacedestroying the dangers of unemployment and inflation.

"3. The development of the necessary safeguards to protect the Government's interest in both the settlement of contracts and the disposal of property; including 
not only adequate records but also protective methods for the prevention and detection of fraud.

"4. On the clearance of Government-owned materials and equipment from the plants of both prime and subcontractors, we have set for ourselves the objective of assuring prompt clearance with a deadline of not later than 60 days after the filing of inventory lists, and with manufacturers having the right to remove and store this property at an earlier date at their own risk."

On July 7, 1943, the War Department issued a termination accounting manual for fixed-price supply contracts (TM 14-320), and on August 20, I943 issued procurement regulation No. 15 defining the principles of the War Department with respect to termination of contracts for the convenience of the Government. These two documents are in for revision to comply with the uniform termination article and the statement of cost principles issued by the Office of War Mobilization. However, since the statement of cost principles issued by War Mobilization Director Byrnes is very brief, and since the principles are substantially in accord with PR-I5, our analysis of the accounting problems will be predicated on the War Department's regulations, as well as the statement of cost principles of the Office of War Mobilization.

The Government procurement departments have entered into a variety of types of contracts such as fixed-price supply contracts, fixed-price construction contracts, cost-plus-a-fixed-fee contracts, and preliminary contractual instruments. This article will be limited to a discussion of the problems incident to fixed-price supply contracts since those problems are, in general, common to all other types of contracts.

The accounting problems incident to fixed-price war contract terminations embrace:
A. Basis of Settlement.
B. What Constitutes Recognized Commercial Accounting Practices.
C. Elements of Cost.
D. Verification Procedures.
E. Disposal of Materials.
F. Methods of Settlement.
G. Settlement Expenses.
H. Financial Statement Presentation.

\section{Basis of SeTtLement}

The uniform termination article provides that settlement for terminated war contracts may be determined in one of two ways, namely,

"(c) The contractor and the contracting officer may agree upon the whole or any part of the amount or amounts to be paid to the contractor by reason of the total or partial termination of work ...., which amount or amounts, may include a reasonable allowance for profit...." 
"(d) In the event of the failure of the contractor and contracting officer to agree as provided in paragraph (c) upon the whole amount to be paid to the contractor ...., the Government, but without duplication of any amounts agreed upon in accordance with paragraph (c) shall pay to the contractor the following amounts:

"I. For completed articles delivered to and accepted by the Government (or sold or retained ...) and not thereafter paid for, forthwith a sum equivalent to the aggregate price for such articles" computed in accordance with the price or prices specified in the contract.

"2. In respect of the contract work terminated ...., the total (without duplication of any items) of (a) the cost of such work exclusive of any costs attributable to any articles paid for or to be paid for under paragraph I hereof, (b) the cost of settling and paying claims arising out of the termination of work under subcontracts or orders ...., (c) a sum ... not exceeding $6 \%$ of the whole amount determined under subdivision (a) ...."

" 3 . The reasonable cost of the preservation and protection of property incurred (in connection with the contract) and any other reasonable cost incidental to termination of work under the contract, including expense incidental to the determination of the amount due to the contractor as the result of the termination of work under this contract.

"The total sum to be paid to the contractor under subdivisions (I) and (2) of this paragraph (d) shall not exceed the total contract price reduced by the amount of payments otherwise made and by the contract price of work not terminated."

Late in September, I943, the Comptroller General contended that the right assumed by the procurement agencies under the First War Powers Act to negotiate termination settlements which would be final, and would not be subject to audit and approval by the General Accounting Office, was an unwarranted usurpation of his powers. The Undersecretary of War and representatives of the other procurement agencies countered with the contention that a termination settlement did not constitute the settlement of a claim against the Government over which the Comptroller General would have jurisdiction, but constituted the negotiation of the adjustment of a valid contract price upon termination of the contract. Subsequently, the Comptroller General conceded that the procurement agencies did have the right to negotiate termination settlements.

Since a termination settlement determined by negotiation between the procurement agency and the contractor constitutes a supplemental agreement as to a sum reasonably necessary to compensate the contractor for work done in respect to the terminated contract, that is tantamount to saying that the amount should represent a sum that would have been considered fair at the time the contract was entered into had the contract called for only the work done to point of termination. 
The Controllers Institute of America in its recommendations relative to war contract terminations released on November 8 , I943, recommended that the basis of termination settlements be defined as follows:

"A termination settlement should represent the fair price to be paid to the contractor for work actually performed on the uncompleted portion of the contract, and should amount to what would have been considered a fair price when the contract was entered into had the contract called for only the work done to point of termination."

Therefore, the settlement should comprise all of those elements which the contractor would have included in his computations when determining the price that he would have quoted for just that amount of work, i.e., the cost of materials, direct labor, direct engineering, patterns, tools, jigs, fixtures, and proper allocation for factory expenses and commercial expenses.

Recognizing that it is necessary that war contracts be subject to change or termination at the option of the Government, war contractors have agreed to the inclusion of termination clauses in their contracts which provide for much less recovery than they would be entitled to receive under the common law or the Uniform Sales Act upon breach of contract. The contractor, however, should not be penalized still more by shortsighted policies governing termination settlements. So long as a war contractor has sufficient orders so that full production can be maintained even though some contracts are terminated, the amounts recovered under termination settlements are not significant because it is probable that high excess profits taxes and refunds under renegotiation will result in returning to the Government all, or substantially all, of the amount recovered in excess of the inventory value of the terminated contracts. Since inventory values do not, as a rule, include any amount for commercial expenses charged off on the books as period expenses, that is tantamount to saying that, if excess profits are earned, the Government will recover all such expenses included in the settlement and the allowance for profit. However, when the inevitable day comes that terminations will be experienced without other contracts to take their place, at which time profits probably will be small or losses sustained, the amounts recovered in termination settlements become very pertinent. It is only from such amounts that the contractor can recover the essential working capital that is invested in war contracts in process that will be needed to finance the transition to peace production. It is essential, therefore, that the Government's policies be sufficiently broad so that the contractor will be able to recover his full investment in the contract.

\section{What Constitures Recognized Commercial Accounting Practices}

Early termination clauses issued by the Procurement Departments generally stipulated (if any stipulation at all was made) that the costs applicable to the terminated contract were to be determined in accordance with "accepted accounting principles." The War Department's termination manual (TM 14-320) used the phrase, "In accordance with recognized accounting practices." The statement of cost principles issued by the Office of War Mobilization states, under General Principles of Costs, the following: 
"The costs contemplated by this statement of principles are those sanctioned by recognized commercial accounting practices and are intended to include the direct and indirect manufacturing, selling and distribution, administrative and other costs incurred which are reasonably necessary for the performance of the contract, and are properly applicable or apportionable, under such practices, to the contract (or the part thereof under consideration)." It is also stated that, "To the extent that they conform to recognized accounting practices ... the established accounting practices of the contractor as indicated by his books of account and financial reports will be given due consideration in the preparation of statements of cost for the purpose of this Article."

The contractor should not be penalized by being required to predicate his claim on accounting methods evolved for normal commercial trading if those methods do not result in a fair determination of his investment in the uncompleted contract. In cost accounting for completed products, methods used for overhead application are intended to determine, as far as practicable, the correct costs of the completed products. It does not necessarily follow that consistent use of those methods will produce the proper cost of the completed portion of a partially completed contract. Therefore, in such cases, the contractor should be permitted to substitute other methods for application of overheads which will result in a more equitable determination of the settlement.

Except in the instances of those contractors organized or completely reorganized for war production, it is unlikely that the established cost accounting methods used for computing completed product costs will reflect the true cost status of an uncompleted contract at the time it is terminated. This will be particularly true in the machinery manufacturing industry where heavy indirect expenses usually absorbed in overheads are incurred in the early stages of the contract. So-called. recognized commercial accounting practices are designed for determination of cost of completed contracts and the sequence of incurrence of indirect expenses (which: are generally absorbed as period expenses when incurred) is not considered. For instance, when calculating the cost of a completed contract, it is of no significancewhether the commercial expenses were incurred before manufacturing expenses or vice versa, so long as the amounts included in the total cost for each type of overhead are proper. That is not true when calculating costs of terminated uncompleted contracts; the methods used for allocating indirect overheads to completed contracts based, say, on factory cost of production, might result in a completely distorted picture when applied to the accumulated factory costs of an uncompleted contract. This would be particularly true if heavy indirect expenses are incurred in the early stages of a contract and the contract is canceled when little or no fabrication has been done.

There should be no particular problem in determining the direct costs of material, labor, design engineering, patterns, tools, etc., which are usually charged to the contract, nor with respect to the overheads directly attributable thereto, since those overheads are normally incurred coincident with production and, generally speaking, if there has been no production, then it should not be proper to contend that any substantial portion of those expenses should be includable in the termina- 
tion settlement. ${ }^{1}$ In the machinery manufacturing industry where machines are built to customers' specifications and the production cycle is of many months' duration, indirect engineering and administrative expenses are significant items of cost which are substantially incurred prior to the start of fabrication. Those overheads are generally charged to operations as period expenses when incurred and are not treated as a product cost except statistically. Contractually they are allowed as product costs under most war contracts. In making statistical application of the indirect engineering and administrative expenses to determine total cost, they are generally applied at standard percentages of factory cost of production, or on some other similar basis. This practice is expedient but not necessarily logical. Therefore, it is apparent that, in order to determine the true cost applicable to a terminated contract under such circumstances, methods used for determination of costs of completed contracts should not be considered as the "recognized commercial accounting practices" which the contractor must follow in determining an equitable claim for termination settlement. The contractor should be permitted to use some other equitable basis in the computation of his settlement claim and should not be restricted to methods employed for commercial contracts. ${ }^{2}$

Another provision of the statement of cost principles which greatly restricts the meaning of the term "recognized commercial accounting practices" is the stipulation that "costs which, as evidenced by accounting statements submitted in renegotiation under Section 403 of the Sixth Supplemental National Defense Appropriation Act, 1942, as amended, were charged off during a period covered by a previous renegotiation, may not be subsequently included in the termination settlement if a refund was made for such period, or to the extent that such charging off is shown to have avoided such refund." This provision is predicated on the theory that, if a contractor has "benefited" by the deduction of certain expenses in determining profits subject to renegotiation, he should not be entitled to receive the benefit of those expenses again through inclusion thereof in the termination settlement base. This is inconsistent with the theory that the negotiated settlement constitutes an adjustment of the selling price. In determining a fair selling price for work to be done, the contractor and the contracting officer do not consider the effect on renegotiation of indirect expenses to be incurred and charged off in a period prior to the period in which the goods covered by the contract are to be shipped. Contractors whose production cycle is short will not be greatly affected by this provision, but contractors whose production cycle stretches over many months could be very adversely affected.

At the beginning of the war production cycle, the producer of capital goods requiring many months to design and fabricate, absorbed against profits derived from commercial shipments, a substantial amount of indirect engineering and other commercial expenses incurred incident to the start of war production. Consequently, no charge has been made for those expenses against profits from war pro-

${ }^{1}$ H. T. McAnly, Cost Accounting as Applied to Contract Termination (Jan., 1944) 12 THE ConTROLLER 20.

"Dundas Peacock, War Contract Termination (March, r943) 75 Jour. of Accountancy 219. 
duction subject to renegotiation. Unless the contractor is permitted to recover equivalent expenses through his termination settlements, he is likely to be severely handicapped for funds to finance the transition to peace production during the months that will be required before he can again begin shipping to commercial customers.

To confuse renegotiation and termination will unnecessarily complicate and delay termination settlements. In those instances where the profit recorded in a period subject to renegotiation was determined to have been reasonable and therefore no refund was made to the Price Adjustment Board, it will be necessary to determine whether the exclusion from the financial statements upon which renegotiation was based of any expenses incurred in that period would have resulted in increasing the profit to a point where a refund would have been required. This would necessitate constant reference, in all such cases, to the Price Adjustment Board to determine what its findings would have been under the changed conditions and, theoretically at least, should require the Price Adjustment Board and the contractor to agree thereto.

In the case of the contractor who has been required to make renegotiation refunds, the effect of the restrictive provision is to deny him the right to recover in his termination settlement any indirect expenses incurred in a prior fiscal period which were treated on his books as a period cost. In computing his claim for a contract canceled early in the year, he would be limited in the amount he could include, to expenses incurred during the year in which the contract was terminated, which might be little or nothing. The following illustration will emphasize that point:

Contract price $\$ 286,000$

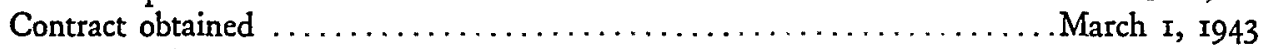

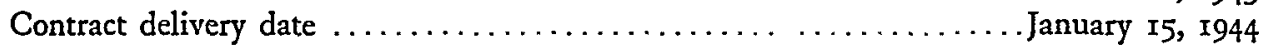

Contract terminated January 2, I944

Costs incurred to termination date:

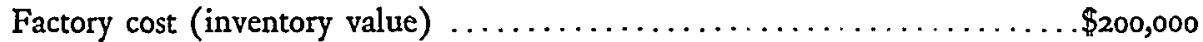

Indirect expenses (charged off as period cost as incurred) . . . . . . . . . . $\frac{50,000}{\$ 250,000}$

Costs necessary to complete:

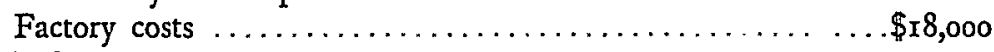

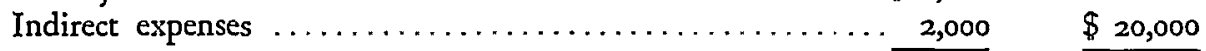

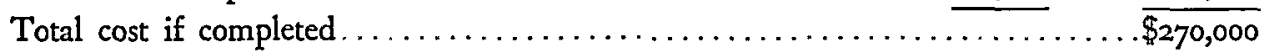

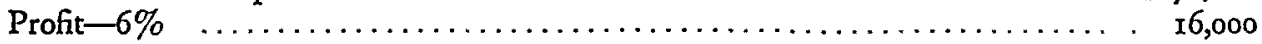

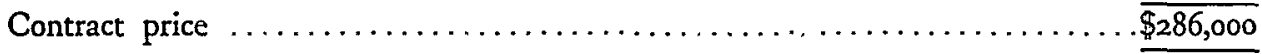

The termination settlement as of January 2, I944, would be restricted to:

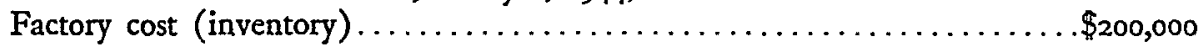

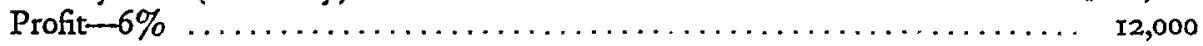

$\$ 212,000$ 
No amount could be included for indirect expenses since they were incurred during a prior fiscal year which will be subjected to renegotiation. It might be contended that, since the year I943 had not been renegotiated when the contract was terminated, the indirect expenses could be deferred at December 3I, I943 and included in the claim. To do so would be inconsistent with past practices; would understate the charges against I943 results of operations; would overstate 1943 profits; and would result in an equivalently greater refund under 1943 renegotiation. Therefore, the increased recovery on termination settlement would be an illusion.

Had the contract not been terminated, additional expenditures necessary to complete it to the extent of $\$ 20,000$ would have been necessary. The contractor would then have been entitled to collect the full contract price of $\$ 286,000$ or $\$ 74,000$ more than he would be allowed upon termination as of January 2, 1944.

In other words, a contractor should either be entitled to recover an appropriate amount for period expenses in the termination settlement or it should be recognized that the profit earned upon completion of a contract when indirect expenses are treated as period expenses is the "gross profit before deduction of period expenses," and not the "net profit after deduction of period expenses."

It is difficult to understand why such a provision is considered necessary or equitable when termination settlements are, in turn, subject to renegotiation (War Department ruling effective February 3, r944).

Unless a more liberal attitude is taken as to what constitutes recognized commercial accounting practices, many contractors will nòt recover their full investment in terminated contracts and will not have the necessary funds to finance the transition to peace production.

\section{Elements of Cost}

So far, we have dealt only with the broad aspects of the accounting problems incident to war contract terminations. There are a number of cost problems which will be complicated and will cause disputes and delays. These problems will vary in importance for different industries. It is not possible to discuss, within the limits of this article, all of the elements of allowable costs which will be significant to all industries. Therefore, we will confine our remarks to only a few of the more important items.

\section{Common Inventory}

The cost of common items (raw materials or work in process) may be included to the extent that the quantities of such items have been properly allocated between the work under the contract and other work.

The inclusion of common items may be accomplished by several different methods and it is not necessary that the same method be followed with respect to all common items involved in a particular termination. Any methods which result in equitable allocation in the particular case will be acceptable, but in no event can the quantities allocated to the terminated contract exceed those which would. 
have been required to complete the contract. When the contract was to have extended over a long period of time, the problem may be complicated by the necessity for determining the amount of material which reasonably should have been acquired up to point of termination for use on the contract.

\section{Depreciation}

Depreciation may be included as an element of cost at appropriate rates, based on wear and tear, on buildings, machinery and equipment and other facilities including such amounts for obsolescence due to progress in the arts and other factors as are ordinarily given consideration in determining depreciation rates. "Appropriate rates" are not necessarily the rates allowed for Federal income tax purposes. It does not appear likely that amortization of facilities required under certificates of necessity will be recognized as an element of cost to the extent that such amortization exceeds appropriate depreciation that would have been provided had the assets not been covered by certificates of necessity.

\section{Loss on Special Facilities}

The statement of cost principles provides that the contractor may claim allowance for the cost of special facilities "acquired for the performance of the contract, or the contract and other war production contracts, if, upon termination of the contract, such facility is not reasonably capable of use in the other business of the contractor. ..." The amount which may be included "must bear the same proportion to the loss of useful value as the deliveries not made under the contract bear to the total of the deliveries which have been made and would have been made had the contract and the other contracts been completed. ..." "The amount to be allowed ... shall not exceed the adjusted basis of the facility for Federal income tax purposes immediately prior to the date of the termination of the contract, and provided further that no amount will be allowed ... unless ... title to the facility is transferred to the Government, except where the Government elects to take other appropriate means to protect its interests."

\section{Experimental and Research Expense}

The statement of cost principles provides that "general experimental and research expense will be recognized as an element of cost to the extent that the amount claimed is consistent with an established pre-war program, or to the extent related to war purposes." When experimental work clearly relates to new postwar products, such expense probably will not be recognized as an allowable item of cost. Continuing developmental work for improvement of standard products will be allowed to an extent comparable with an established pre-war program.

\section{Special Leases}

Rentals under leases made for the performance of war production contracts, covering the period necessary for complete performance of the contracts and such 
further period as may have been reasonably necessary, may be included as an element of cost. Costs of reasonable alteration of such leased property made for the purpose of performance of the war contract and costs of restoring the premises, to the extent required by reasonable provisions of the lease, less the residual value of the lease, may also be included as an element of cost to an appropriate extent. The contractor, however, is required to make reasonable efforts to terminate, assign, or settle such leases, or otherwise reduce the cost thereof in order to be entitled to include the lease expense as an element of costs. It is interesting to note that the Government recognizes the cost of restoring leased premises when required by the lease, although it has denied the contractor the right to make provision for reconversion of his own properties which would be deductible for 'income tax or renegotiation purposes or includable as an element of cost in termination.

\section{Advertising}

Advertising bids fair to be a rather controversial item. The statement of cost principles states that "advertising expense to the extent consistent to a pre-war program or to the extent reasonable under the circumstances" should be included to the extent that it is allocable to, or should be apportioned to the contract or the part thereof which has been terminated. The General Accounting Office has never recognized advertising as an item of cost that is necessary to performance under a Government contract. However, due to the recognized necessity for war producers to advertise to keep their name before their customers and due to the necessity for subcontractors advertising for the edification of prime contractors, some formula undoubtedly will be devised, possibly as follows:

(a) Prime contractors will be allowed an appropriate percentage of institutional advertising, but no amount for product advertising.

(b) Subcontractors will be allowed an appropriate percentage of product and institutional advertising.

\section{Other Elements of Costs}

The aggregate amounts allowable for overhead may not "exceed the amount which would have been available from the contract price to cover these items, if the contract had been completed after considering all other costs which would have been required to complete it." Where it is indicated that a loss would have been sustained on the contract had the contract been carried to completion, the amount allowable for direct and indirect costs will have to be adjusted accordingly.

Initial loading costs, or costs of a non-recurring nature, which arise from unfamiliarity with the product in the initial stages of production, should be appropriately apportioned between the completed and the terminated portions of the contract. In other words, high initial costs which have not been recorded for amortization over all of the units to be produced under the contract can be removed from the recorded costs of the completed units already delivered and properly apportioned between the completed and the terminated portions of the contract. In this 
category would be included high direct labor and overhead costs, including training of personnel, costs of excessive rejections, etc. If costs of the completed units had been included in results of operations subjected to renegotiation, restatement would not be allowed.

The statement of accounting principles also provides that the following items should not be included as elements of cost:

"(a) Losses on other contracts, or from sales or exchanges of capital assets; fees and other expenses in connection with reorganization or recapitalization, antitrust or Federal tax litigation or prosecution of Federal income tax claims or other claims against the Government; losses on investments; provisions for contingencies; and premiums on life insurance where the contractor is the beneficiary.

"(b) The expense of conversion of the contractor's facilities to uses other than the performance of the contract.

"(c) Expenses due to the negligence or willful failure of the contractor to discontinue with reasonable promptness the incurring of expenses after the effective date of the termination notice.

“(d) Costs incurred in respect to facilities, materials, or services purchased or work done in excess of the reasonable quantitative requirements of the entire contract."

You will note that provisions for contingencies and expenses of conversion are denied as elements of cost. In view of the fact that the Bureau of Internal Revenue and the Price Adjustment Boards have already denied to war contractors the right to provide reserves for wartime contingencies such as separation allowances, deferred maintenance, inventory losses, etc., it seems unreasonable that at the point where such losses become imminent, they should also be denied as elements of cost. Certainly the war production cycle will not be completed, nor will the profits derived from war production be determined until all of these contingencies have become realities and the expenses and losses incident thereto have been incurred or sustained.

It is equally true that the cost of reconverting properties that were converted for war production so that they may again be utilized in peace production is an element of war contract cost and should be recognized as such, either by the Price Adjustment Boards, or the procurement agencies in determining termination settlements. For the Government to assume responsibility for conversion of plants to war production and to deny responsibility for reconversion to the approximate condition that existed before the start of war production, is obviously inequitable.

\section{Verification Procedures}

When decision has been made to terminate all or a portion of a contract, the contracting officer is required to serve notice of termination on the contractor and to advise him as to ( $I$ ) the effective date of the termination, (2) the performance to be discontinued, (3) any special directions as to the protection of Government property, etc. 
Upon receipt of the termination notice, the contractor is required by the uniform termination article to do the following:

I. Terminate work under the contract on the date and to the extent specified in the notice of termination.

2. Place no further orders or subcontracts for materials, services, or facilities except as may be necessary for completion of such portions of the work under the contract as may not be terminated.

3. Terminate all orders and subcontracts to the extent that they relate to the performance of any work terminated by the notice of termination.

4. Assign to the Government, in the manner and to the extent directed by the contracting officer, all of the right, title, and interest of the contractor under the orders or subcontracts so terminated.

5. Settle all claims arising out of such termination of orders and subcontracts with the approval or ratification of the contracting officer to the extent that he may require, which approval or ratification shall be final.

6. Transfer title and deliver to the Government in the manner, to the extent, and at the times directed by the contracting officer (a) the fabricated or unfabricated parts, work in process, completed work, supplies and other material produced as a part of, or acquired in respect of the performance of, the work terminated in the notice of termination, and (b) the plans, drawings, information, and other property which, if the contract had been completed, would be required to be furnished to the Government.

7. Use his best efforts to sell in the manner, to the extent, at the time, and at the price or prices directed or authorized by the contracting officer, any property of the types referred to in item 6 . However, the contractor (a) shall not be required to extend credit to any purchaser, and (b) may retain any such property at a price or prices approved by the contracting officer.

8. Complete performance of such part of the work as shall not have terminated by the notice of termination.

9. Take such action as may be necessary or as the contracting officer may direct for protection and preservation of the property which is in the possession of the contractor and in which the Government has, or may acquire, an interest.

The troublesome requirements included above are:

(a) That the contractor is required to settle all claims arising out of termination of orders and subcontracts subject to the approval or ratification of the contracting officer.

(b) That he is obligated to use his best efforts to sell the materials acquired for the contract at prices directed or authorized by the contracting officer.

It is likely that it will be found impracticable to hold the prime contractors responsible for the examination and settlement of claims of subcontractors and suppliers. Many prime contractors are small concerns whose subcontractors are large concerns and it would be obviously impracticable for the small prime contractor 
to review and examine the voluminous and complicated records of the large subcontractor.

The work of verifying termination settlement claims can be divided into three phases, namely (I) determination of the propriety of the methods used in computation of the claims, (2) test check of the component costs and expenses entering into the claims, and (3) the determination of the legal right of the contractor to make the claims. In the case of a company which has settlement claims to submit arising from numerous terminated prime contracts and subcontracts of varying degrees, the audit work incident to verification of all of those claims would be minimized and simplified if provision were made for a Government auditor from the procurement department having a preponderance of interest in the terminated contracts and subcontracts from which the claims arise, to undertake the verification of the methods and components of the claims on behalf of all of the war agencies concerned. The auditor would be concerned only with (I) determining the propriety of the methods used in computation of the claims, and (2) testing the component costs and the propriety of the expenses entering into the claim.

Obviously the method employed by the contractor in determining his settlement claims should be consistent for all claims, so that the auditor having once satisfied himself as to the propriety of the method would not need to repeat that work for subsequent claims. Inquiry into the contractors' methods of accumulating direct costs against contracts, and adequate test checks of the costs entering into selected claims, should suffice to assure the auditor of the general accuracy of the component prime costs of all of the claims. Since overheads would be applied ratably to all settlement claims on consistent bases, tests that would be made to determine the propriety of the items included in the overhead and consideration of the logic of methods of application would complete that work for the whole group of claims.

The alternative to such a procedure is the verification of each contractor's claims arising under each terminated prime contract and subcontract by a succession of auditors from the various procurement agencies and the prime contractors. Each of those auditors would necessarily have to satisfy himself as to the propriety of the methods used and of component costs and expenses. Such a procedure would constitute an unnecessary waste of the country's accounting talent, which will be severely taxed to accomplish the necessary verification, even under an overall verification method such as has been suggested.

Under the overall method of verification, the auditor would satisfy himself that each claim appeared to be reasonable when compared with the selling price contained in the terminated prime contract or subcontract. Upon completion of his verification work, the claims incident to prime contracts would be transmitted to the procurement agency which awarded the contract, for consideration of the contracting officer and final approval. Claims arising from subcontracts would be transmitted to the prime contractor or superior subcontractor, bearing the stamp 
of approval of the Government auditor as to method of computation and component costs, expenses, and profit factor. The prime contractor's or superior subcontractor's responsibility then would be limited to determination that a contract had in fact been awarded to the subcontractor under a contract that had been terminated. After determining the amount of partial payments made to the subcontractor or other offsets against the claim, the net claim would be determined and then transmitted to the procurement agency that awarded the prime contract for final approval and payment.

It is not intended to infer that all claims should be subject to audit. It is believed that the interests of the Government will be amply protected if reliance is placed on intelligent review of claims rather than detailed audits. In cases where audits appear to be necessary, they should be carried out in accordance with the principles of selective auditing. When an overall method of verification such as has been suggested is employed, the auditor should be able to make sufficient tests of selected claims to satisfy himself as to the propriety of all claims under review.

Inasmuch as the announcement that was made at the time of the release of the uniform termination article stated that it had not yet been determined how to apply the principles of the uniform termination article to subcontractors because of serious administrative problems that required further study, it is possible that an overall procedure such as we have suggested will be adopted.

It is important that all contractors and subcontractors involved in war production should familiarize themselves with the verification procedures adopted by the procurement agencies with whom they will be dealing.

As soon as possible after notice of termination is received, all work should be stopped in accordance with the notice of termination and a complete physical inventory should be taken of all materials acquired or produced for the contract. The inventory should be arranged according to raw materials, work in process, manufactured parts, and completed goods not yet shipped and should be carefully prepared and record kept of the employees who made the count, who checked the count, and the dates on which the counts and checks were made. Inasmuch as the materials inventoried which constitute the basis for the claim against the Government will have to be transferred to the Government or disposed of in accordance with the instructions of the contracting officers, care must be exercised to assure the protection of the property, for it is provided in the uniform termination article that "there shall be excluded from the amounts payable ... all amounts allocable to or payable in respect of property which is destroyed, lost, stolen, or damaged so as to become undeliverable prior to the transfer of title to the government or to a buyer ... prior to the 6oth day after delivery to the Government of an inventory covering such property." Presumably, the Government is supposed to assume full responsibility for storage and loss after 60 days after the inventory 
has been prepared and delivered to the Government, always excepting, of course, negligence on the part of the contractor.

Inventories should be valued in accordance with generally accepted practices. Where a contractor has been following the practice of costing on a last-in-first-out basis, it may be contended that he must adhere to that practice in computing the termination claim. However, it can readily be demonstrated that many contractors will be adversely affected if they are not permitted to evaluate the inventory at actual cost in place of the "LIFO" cost under certain circumstances.

The accounting manual issued by the War Department was predicated on examination of prime contractors' claims being limited to an office review of the claim. If the contracting officer decided that some further examination of the contractor's proposed settlement should be made beyond the office review, the contractor may be requested to submit additional data or explanations in writing. If the contracting officer is still not satisfied, Government accounting personnel will be instructed to visit the contractor's plant to discuss the statement and to make any necessary reference to the accounting records. If, in the contracting officer's opinion, an audit of the records is necessary, it will be made by the accounting personnel. The accounting manual stresses the fact that auditing must be reduced to a minimum consistent with protecting the interests of the Government. In cases where audits appear to be necessary, they are to be carried out in accordance with the principles of selective auditing.

\section{Disposal of Materials}

As stated previously, the uniform termination article requires the contractor:

(a) To protect the materials acquired or produced for the terminated portion of the contract, and

(b) To use his best efforts to sell the property in the manner, to the extent, at the time, and at the price or prices directed or authorized by the contracting officer.

It is fortunate that the Government apparently intends to dispose of the materials within 60 days after the inventory has been filed, or to take possession thereof, or to assume responsibility for damage thereto not due to the negligence of the contractor. When a large number of war contract terminations is experienced, many contractors and subcontractors will be unable to commence peace production until the materials acquired for war contracts have been removed from their plants. There will not be sufficient suitable storage space available in the country to make it possible for such materials to be stored by the contractors and subcontractors for an indefinite period of time. Obviously, uncontrolled dumping of those materials on the open market would be very undesirable from the standpoint of maximum recovery by the Government, and from the standpoint of stabilization of the material markets. Therefore, after the 6o-day period stipulated in the uniform termination article, the contractor should have the right to store the 
materials at Government risk and expense if disposition of the material has not been completed by the surplus property administrator responsible for disposition of surplus materials. It will be necessary for regulations relative to disposition of materials to state clearly when the contracting officer should decide to dispose of surplus materials and work in process as scrap, and when he should certify the material to the surplus property administrator for disposition. Unless contracting officers can use broad judgment in determining disposition of materials without fear of criticism by persons having the benefit of hindsight, it is possible that they will be loathe to order scrapping when in doubt. Such an attitude on the part of the contracting officers could greatly increase the cost of terminations and seriously delay the settlements.

The problems incident to disposition of surplus materials are legion and far beyond the scope of this article; therefore, nothing further will be said herein except to recommend very strongly that all contractors prepare in advance for protection and storage of those materials, since the materials constitute the basis for supporting their termination claims.

\section{Methods of Setrlement}

As stated previously, the uniform termination article provides for two methods of settlement:

I. By agreement between the contractor and the contracting officer as to the whole or any part of the amount or amounts to be paid to the contractor by reason of the total or partial termination of work, which amount or amounts may include a reasonable allowance for profit.

2. In the event of failure of the contractor and contracting officer to agree upon the whole amount to be paid to the contractor by reason of the termination of work, the Government shall pay:

(a) For completed articles delivered to and accepted by the Government, a sum equivalent to the aggregate price for such articles computed in accordance with the price or prices specified in the contract.

(b) The cost of uncompleted work, plus an allowance for profit not exceeding $6 \%$ of the total cost.

(c) The reasonable cost of the preservation and protection of property and any other reasonable cost incidental to termination work under this contract, including expense incidental to the determination of the amount due to the contractor as the result of the termination of work under this contract.

It is stipulated in the uniform termination article that it shall not be assumed that the amount which the contractor and the contracting officer may agree upon as being a fair termination settlement is limited to the amount which may be determined in accordance with the formula to be used in the event of failure to agree. Presumably, the agreed upon amount could be greater or less than the amount determinable by the formula method. However, inasmuch as the con- 
tracting officer will be required to support any agreed upon settlement by documentary evidence, we believe it is safe to assume that the settlement by agreement will generally approximate the amount which would be determined by the formula method, and seldom will exceed that amount except when extenuating circumstances exist which clearly justify his action.

Both the uniform termination articles and statement of cost principles issued by the Director of War Mobilization are confined to broad principles. Details are to be covered by administrative regulations, manuals, and instructions which will be issued by the procurement agencies to conform with the organizational setup of each agency. Unfortunately, each of the procurement agencies has its own organizational setup so that it is not practicable for detailed regulations to be adopted which would be applicable to all of the agencies. As yet, the agencies have not had time to issue their manuals since the uniform termination article was released. We can only assume that the procedure to be followed will be similar to that adopted by the War Department in its procurement regulation No. 15, as follows:

I. It is the responsibility of the contracting officer to determine a proper settlement guided by the accounting data and reports prepared by the accounting personnel.

2. A group of three or more responsible officers or civilian employees of the War Department is to be designated by the Chief of each technical service for the assistance of the contracting officers engaged in the termination of contracts. The contracting officer is required to submit each proposed settlement agreement involving the payment of more than $\$ 5,000$ (excluding amounts payable for completed items or work at the contract price and before deduction of disposal credits) for examination by the advisory section prior to the execution of the settlement agreement. The functions of the settlement advisory sections are advisory only and the contracting officer may decide not to accept their advice, but in the event that he does not do so, he is required to prepare a written memorandum of his reasons for not doing so.

3. Each settlement agreement involving the payment of more than $\$ 1,000,000$ will be reported (after the review by the appropriate advisory section) to a settlement review committee of the technical services.

4. A copy of each settlement agreement providing for a payment in excess of $\$ 5,000,000$, together with an adequate statement of the basis upon which such settlement was made, is required to be submitted, after the same has been executed, to the Director, Purchases Division, Headquarters Army Service Forces.

\section{SETtLement Expenses}

The formula provided in the uniform termination article provides for payment to the contractor, in addition to costs incurred to point of termination, of the following: 
"The reasonable cost of the preservation and protection of the property incured ....; and any other reasonable cost incident to termination of work under this contract, including expense incidental to the determination of the amount due to the contractor as the result of the termination of work under this contract."

Among the expenses which will be recognized as reimbursable under that provision are the following:

\section{Settlement Expenses}

Reasonable accounting, legal, clerical, and other expenses necessary in connection with the settlement of the contract, and subcontracts and purchase orders thereunder, including expenses incurred for the purpose of obtaining payment from the Government, only to the extent reasonably necessary for the preparation and presentation of settlement proposals and cost evidence in connection therewith.

\section{Protection and Disposition of Property}

Storage, transportation and other costs incurred for the protection of property acquired or produced for the contract, or in connection with the disposition of such property.

The above expenses are in addition to the amount determined as being applicable to the terminated contract and are not affected by the provision that the costs incurred to point of termination, plus estimated costs necessary to complete the contract, may not exceed the contract price.

\section{Financial Statement Presentation}

It is not likely that published financial statements for the year 1943 will indicate any great uniformity in presentation of termination claims.

Where the termination claims assume significant proportions and are material in amount, obviously they should be set out separately on the balance sheet and included in current assets. Upon termination of a contract, the work in process included in inventory for that contract becomes one of the components which measures the amount of the termination settlement. The other components are the claims of subcontractors for terminated work, the indirect expenses not included in inventory, the profit factor and the possible termination expenses. The summation of all of these factors constitutes the claim against the customer and should be recorded as such in the current asset section of the balance sheet. Until termination procedures, practices and allowable elements of cost are more positively defined, however, most companies will prefer to reflect the claims on the balance sheet at inventory value only, or, if the gross amount of the claim is reflected, to provide an additional amount in the reserve for doubtful accounts for the amount which might not be recovered, depending upon the attitude of the contracting officers and the policies adopted by the procurement agencies. 